\title{
Retraction note to: Expression of a rice chitinase gene enhances antifungal response in transgenic litchi (cv. Bedana)
}

\author{
D. K. Das ${ }^{1}$ - A. Rahman ${ }^{1}$
}

Published online: 2 December 2016

(C) Springer Science+Business Media Dordrecht 2016

\section{Retraction note to: Plant Cell Tiss Organ Cult}

(2012) 109:315-325

DOI 10.1007/s11240-011-0097-2

This article has been retracted. The retraction was undertaken at the request of Dr. Das, the corresponding author of this paper, as it was found that this paper included duplicated information already published in Current Trends in Biotechnology and Pharmacy 4 (2010), 820-833, by the same corresponding author, and data that did not correspond to the species studied in this publication.

The online version of the original article can be found under doi:10.1007/s11240-011-0097-2.

D. K. Das

dilipdas1@live.com

1 Post Graduate Department of Biotechnology, T. M.

Bhagalpur University, Bhagalpur 812007, India 